\title{
ESTIMATION OF ANISOTROPIES IN CHLOROPHYLL $A$ SPATIAL DISTRIBUTIONS BASED ON SATELLITE DATA AND VARIOGRAPHY
}

\author{
M. MICHELAKAKI \\ D. KITSIOU*
}

*to whom all correspondence should be addressed Tel: +30 22510 36819; Fax: +30 2251036809 e-mail: dkit@aegean.gr

\author{
Department of Marine Sciences \\ University of the Aegean
811 00, Mytilene, Lesvos, Greece \\ University of the Aegean
University Hill, 811 00, Mytilene, Lesvos, Greece
}

Selected from papers presented in $9^{\text {th }}$ International Conference on Environmental Science and Technology (9CEST2005)

1-3 September 2005, Rhodes island, Greece

\begin{abstract}
Sea eutrophication is a natural process, however in many cases is considered one of the major forms of water pollution affecting coastal areas, lakes and reservoirs all over the world. Many methodologies have been developed for assessing eutrophication and during the last decades, the contribution of remote sensing techniques has been proved very useful in this research area. Satellite data from various sensors have been processed and analysed by research groups all over the world for estimating chlorophyll a concentrations and consequently, eutrophication conditions in the marine environment. Further analysis of the spatial structure of the eutrophication phenomenon that includes detection of the degree of homogeneity and of the directions of maximum / minimum anisotropy is of great interest as well.

In this study, an attempt was carried out for estimating the anisotropy in chlorophyll a spatial distributions produced by the process of satellite data. The North Aegean Sea was used as the case study area and SeaWiFS monthly satellite data acquired for February, May, July and September 2003 were analysed. As a result, four eutrophication maps illustrating the eutrophication levels in the North Aegean Sea were developed and further analysis of their spatial structure was carried out using variograms. Semi- and surface variograms were developed and the directions of minimum / maximum anisotropy as well as the degree of spatial correlation of the eutrophication phenomenon were assessed.
\end{abstract}

KEYWORDS: marine eutrophication, remote sensing, SeaWiFS, variograms, North Aegean

\section{INTRODUCTION}

Marine eutrophication is the natural process of enrichment of water with plant nutrients resulting in the increase of aquatic primary production and leading to visible algal blooms (Vollenweider et al., 1992). However, in many cases, eutrophication is considered one of the major forms of water pollution affecting coastal areas, lakes and reservoirs all over the world. The eutrophication phenomenon is defined by the European Environment Agency (1998) as "The enrichment of waters by inorganic plant nutrients which results in the stimulation of an array of symptomatic changes. These include the increased production of algae and / or other aquatic plants, affecting the quality of the water and disturbing the balance of organisms present within it". A mass of water characterised as 'oligotrophic' corresponds to a low nutrient status and low biological productivity. The term 'mesotrophic' is used for water of medium nutrient 
status and medium biological productivity and finally the term 'eutrophic' represents water that is rich in nutrients and highly productive.

Research has already been carried out to quantify eutrophication at both horizontal and vertical scales using a variety of parameters such as chlorophyll a and nutrient concentrations (Rodhe, 1969; Young et al., 1999) or ecological indices (Washington, 1984; Karydis and Tsirtsis, 1996; Kitsiou and Karydis, 2000); however, in the majority of studies chlorophyll $a$ is considered as the most representative parameter of marine eutrophication.

During the last decades, the contribution of remote sensing techniques in marine eutrophication assessment has proved very important. Ocean color is a unique property measured from satellite sensors to provide synoptic global information on oceanographic parameters that represent the upper ocean from the surface to a few tens of meters depth (Maritorena and Siegel, 2005). To date, most of the quantitative applications of ocean color remote sensing have focused on the determinations of abundance and distribution of phytoplankton chlorophyll in the world's oceans and have succeeded to provide a synoptic coverage of surface patterns of phytoplankton biomass distribution at a global scale (Garcia et al., 2005).

On the other hand, application of geostatistics and variography analysis has been used for assessing eutrophication trends (Kitsiou et al., 2001). The estimation of eutrophication conditions in the marine environment and the analysis of the observed trends at a spatial and temporal scale are of major importance and if they are only based on in-situ measurements carried out by oceanographic vessels are not always appropriate. Therefore, combination of processed satellite data with variography analysis could prove quite useful in eutrophication studies. In this paper, satellite data from the SeaWifs sensor have been processed and analysed using geostatistics for the assessment of the spatial structure of chlorophyll a concentrations and consequently, of eutrophication phenomena. The importance of combining satellite data with such methodologies is revealed by the analysis results.

\section{MATERIALS AND METHODS \\ Study Area}

The Aegean Sea constitutes the north-eastern part of the eastern Mediterranean Sea with a complicated hydrographical and ecological structure due to its geographical position (Siokou-Frangou et al., 2002). The study area that is the North Aegean Sea is connected with the Sea of Marmara through the Dardanelles Straits that are nearly 62 $\mathrm{km}$ long, $1.3-7 \mathrm{~km}$ wide and $55 \mathrm{~m}$ in average deep (Figure 1). In this area, the relatively warm and highly saline waters from Levantine and south-central Aegean are diluted by the less saline water inflow from the Dardanelles and by freshwater outflows from various rivers discharging along the Greek and Turkish coastlines (Zervakis and Georgopoulos, 2002; Krasakopoulou et al., 2002). Moreover, seasonal changes in the meteorological conditions as well as sporadic and strong meteorological events can alter local water circulation patterns (Poulos et al., 1997).

The North Aegean could be classified as a 'continental margin' ecosystem (Lykousis et al., 2002), while studies on bacterial production, phytoplankton biomass, nutrient and chlorophyll a concentrations, revealed its oligotrophic character (Christaki et al., 1999; Kucuksezgin et al., 1995; Siokou-Frangou et al., 2002). Furthermore, Lykousis et al. (2002) mention that the production levels in the North Aegean is somehow higher in relation to those in the

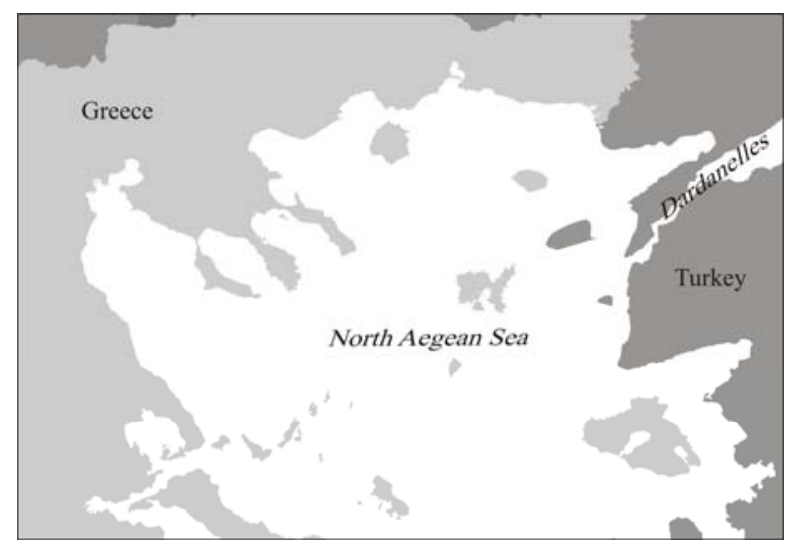

Figure 1. The North Aegean Sea 
South Aegean; however, the entire Aegean Sea can be classified as highly oligotrophic.

\section{Satellite data}

The Sea-viewing Wide Field-of-view Sensor (SeaWiFS) Mission is part of NASA's Earth Science Enterprise and is designed to look at the Earth from space to better understand it as a system in both behaviour and evolution. The SeaWiFS is one of the most important global observational platforms for oceanic biogeochemistry (Gregg and Casey, 2004). Data from this sensor have been used in many applications; development of primary production (Campbell et al., 2002) and ecosystem models (Moore et al., 2002), studies of harmful algal bloom (Fisher et al., 2003; Stumpf, 2001) and phytoplankton biodiversity (Iglesias-Rodriguez et al., 2002; Kamykowski et al., 2002).

In the present work, ocean color Level-3 Standard Mapped Image (SMI) products from SeaWiFS were acquired by the NASA Goddard Space Flight Center - Ocean Color Data Processing System (GSFC-OCDPS). The data processing carried out by the SeaWiFS Data Processing System involved: (a) Atmospheric Correction, (b) Bio-optical Data Analysis, (c) Product Verification, (d) Calibration and Evaluation and (e) Level 3 Data Analysis (McClain et al., 1992; McClain et al., 2004). As a result, four monthly satellite images with a spatial resolution of $9 \mathrm{~km}$ covering the North Aegean Sea in February, May, July and September 2003 were acquired and further processed in order to attribute to each pixel a chlorophyll a concentration value $\left(\mathrm{mg} \mathrm{m}^{-3}\right)$ based on the exponential relation given by The SeaWiFS Project (http://oceancolor.gsfc.nasa.gov). The projection of the satellite data is UTM (Spheroid: GRS 1980, Datum: GRS 1980, Units: meters).

\section{Eutrophication maps}

A eutrophication scale (Table 1) was applied for the categorisation of the chlorophyll a concentrations to four eutrophication levels: oligotrophic, lower-mesotrophic, uppermesotrophic and eutrophic (Karydis et al., 1995). As a result, eutrophication maps for each month under study were produced.

Table 1. Eutrophication scale for chlorophyll a concentrations

\begin{tabular}{cc}
\hline Chloroplyll $\mathbf{a}\left(\mathbf{m g ~ m}^{-3}\right)$ & Eutrophication Level \\
\hline $0.000-0.084$ & Oligotrophic \\
\hline $0.084-0.359$ & Lower-mesotrophic \\
\hline $0.359-0.793$ & Upper-mesotrophic \\
\hline$>0.793$ & Eutrophic \\
\hline
\end{tabular}

\section{Variography}

The variogram is the spatial structure function most frequently used in geostatistics (Herzfeld and Zahner, 2001). It describes the spatial correlation structure of the phenomenon under study (Spokas et al., 2003) and is defined mathematically as (Goovaerts, 1997):

$$
\gamma(h)=\frac{1}{2 n} \cdot \sum_{i=1}^{n}\left\{Z\left(x_{i}\right)-Z\left(x_{i}+h\right)\right\}^{2}
$$

where $Z\left(x_{i}\right)$ is the value of the examined variable at the position $x_{i}, Z\left(x_{i}+h\right)$ is the value of the examined variable at the position $x_{i}+h$ and $n$ is the number of pairs of sample points separated by distance $h$, called lag; since it is impractical to plot a variance for each scatter point with respect to each of the other scatter points the distances are subdivided into a number of intervals (lags). A plot of $\gamma(h)$ against $h$ is known as the sample semivariogram (Burrough, 1996) and contains all the useful information about the spatial variation of the property under study, summarising the general form of the variation, its magnitude and spatial scale (Oliver and Webster, 1990; Spokas et al., 2003). The direction-depended spatial anisotropy is better identified when the experimental semi- 
variogram values are plotted in the system of coordinates $\left(h_{x}, h_{y}\right)$, yielding the semivariogram map or surface variogram (Goovaerts, 1997). In other words, the surface variogram is a 2-dimensional plot represented as a pixel map and is used to detect anisotropies in the pattern of spatial continuity, indicating the precise directions in which they occur (Pannatier, 1996).

Variograms are frequently used for the detection of anisotropies and the degree of homogeneity in a study area (Vázquez et al., 2005; Goovaerts, 1997). In this study, semi- and surface variograms were developed using as input the processed satellite data for the four months under study in order to determine the level of spatial dependence and heterogeneity in chlorophyll a concentrations, as well as the directions of maximum anisotropy or homogeneity.

\section{RESULTS AND DISCUSSION Eutrophication Maps}

The maps illustrating the eutrophication conditions in February, May, July and September 2003 in the North Aegean Sea are given in Figure 2. It is observed that all the eutrophication levels (oligotrophic, lower-mesotrophic, upper-mesotrophic and eutrophic) appear on the maps.

Eutrophic field is mainly observed in coastal areas and especially in the gulfs; however, during May 2003 it is extended between Lemnos Island and the Dardanelles Straits. This observation could be attributed to the input of Black Sea waters through the Dardanelles that result to higher concentrations of chlorophyll $a$ in the neighboring Aegean Sea waters (Ignatiades et al., 2002). Apart from this period, the eutrophication levels in the North Aegean Sea are in general quite low representing lower-mesotrophic to oligotrophic conditions. Two points should be noted here: (a) Ignatiades et al. (2002) characterise the Aegean Sea waters as oligotrophic with an overall average level of chlorophyll a concentrations ranging from 0.119 to $0.371 \mathrm{mg} \mathrm{m}^{-3}$. (b) Gregg and Casey (2004) state that the SeaWiFS sensor overestimates the in-situ data in the Mediterranean Sea, while D'Ortenzio et al. (2002) attribute these overestimates to atmospheric correction (in particular, aerosols).

\section{Variography}

The semi- and surface variograms representing the time periods under study are shown in Figure 3. The maximum values of $y(h)$ are observed in May 2003 and for lags $>300$ $\mathrm{km}$.

The lengths of the major and minor axis of the ellipses that are representative of the surface variograms are given in Table 2. The major axis shows the direction where the examined parameter has the minimum anisotropy, while the minor axis the direction where the maximum anisotropy is observed. The directions of minimum anisotropy are also given in Table 2. It is observed that the length of all the major axis is quite long (the maximum value is observed in May 2003), leading to the conclusion that the degree of homogeneity in the study area is quite high. The same conclusion could be derived by observing the lengths of the minor axes that are quite high as well. The directions where the minimum anisotropy is observed vary; however this variation is always within the range of $\pm 45^{\circ}$ from the North $\left(0^{\circ}\right)$.

These results verify the observations of many researchers that the overall North Aegean Sea is an oligotrophic environment, however, with significant horizontal variability (Siokou-Frangou, 2002). Moreover, though the directions of variability are not permanent throughout the year, not significant changes are observed except during May when the inflow from the Black Sea seems to influence the eastern part of the study area. 


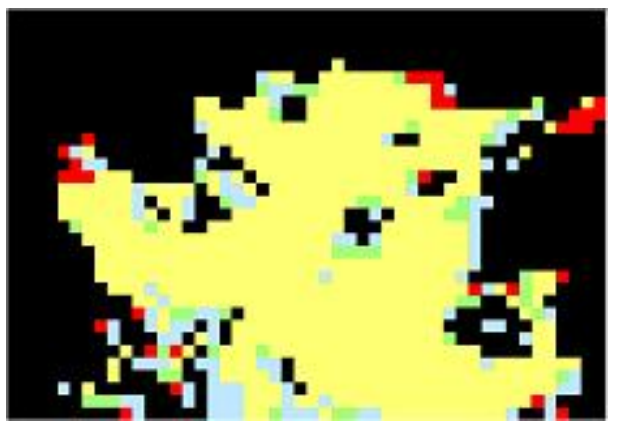

February 2003

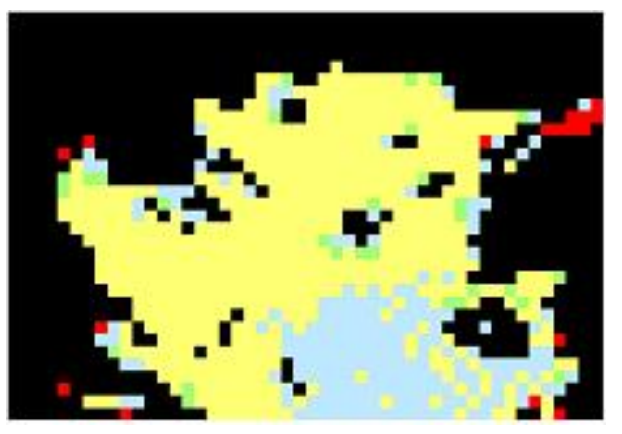

July 2003

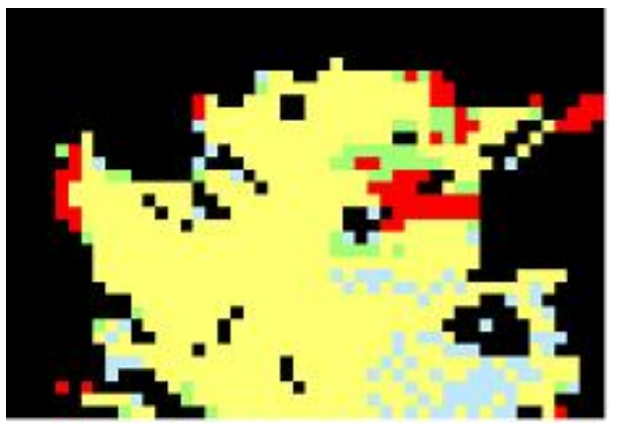

May 2003

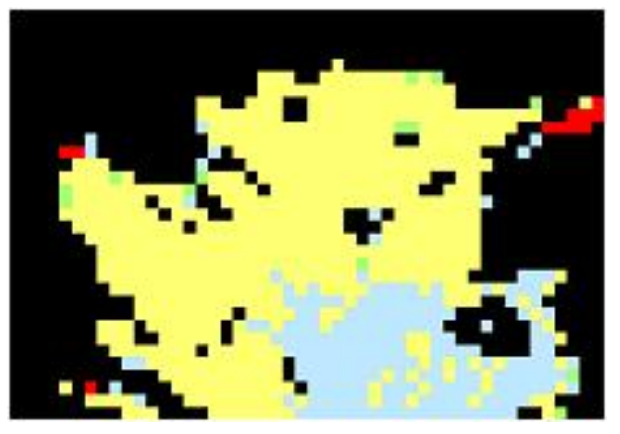

September 2003

\section{$1 \square 2 \square 3 \square 4$}

Figure 2. Eutrophication maps for February, May, July and September 2003.

(1: eutrophic field, 2: upper-mesotrophic field, 3: lower-mesotrophic field, 4: oligotrophic field)

Table 2. Main characteristics of the surface variograms for the four months under study

\begin{tabular}{lccc}
\hline & $\begin{array}{c}\text { Major Axis } \\
\text { Length }(\mathbf{m})\end{array}$ & $\begin{array}{c}\text { Minor Axis } \\
\text { Length }(\mathbf{m})\end{array}$ & $\begin{array}{c}\text { Direction } \\
\text { min anisotropy }\end{array}$ \\
\hline February 2003 & 358880 & 279570 & $45.00^{\circ}$ \\
\hline May 2003 & 359030 & 311230 & $347.42^{\circ}$ \\
\hline July 2003 & 358870 & 247850 & $39.90^{\circ}$ \\
\hline September 2003 & 358250 & 279070 & $25.90^{\circ}$ \\
\hline
\end{tabular}

${ }^{(*)}: 0^{\circ}$ corresponds to the North

\section{CONCLUSIONS}

This study revealed the importance of analysing the spatial distributions of chlorophyll a concentrations, derived from the processing of satellite data, using geostatistical methods. The degrees of spatial correlation and the directions of maximum / minimum anisotropy were detected leading to the conclusion that semi-variograms are an effective way of analysing the spatial behaviour of the parameter under study. Additionally, the surface variograms indicate with precision the directions where different degrees of anisotropy are observed. This analysis could be very useful when eutrophication conditions and trends should be assessed in a quite extended area such as the North Aegean Sea, which is characterised by a certain degree of variability though been representative of oligotrophic conditions. 

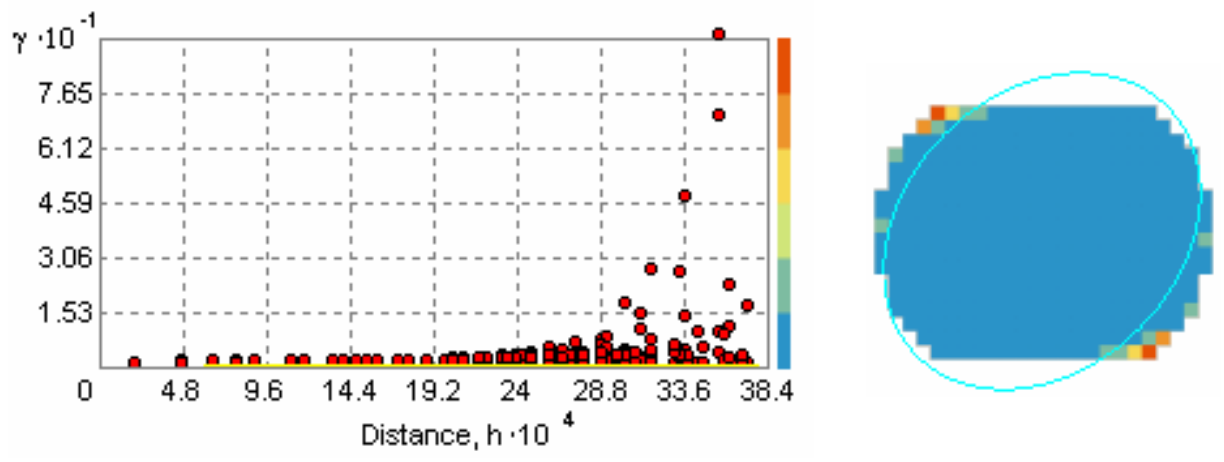

(a)
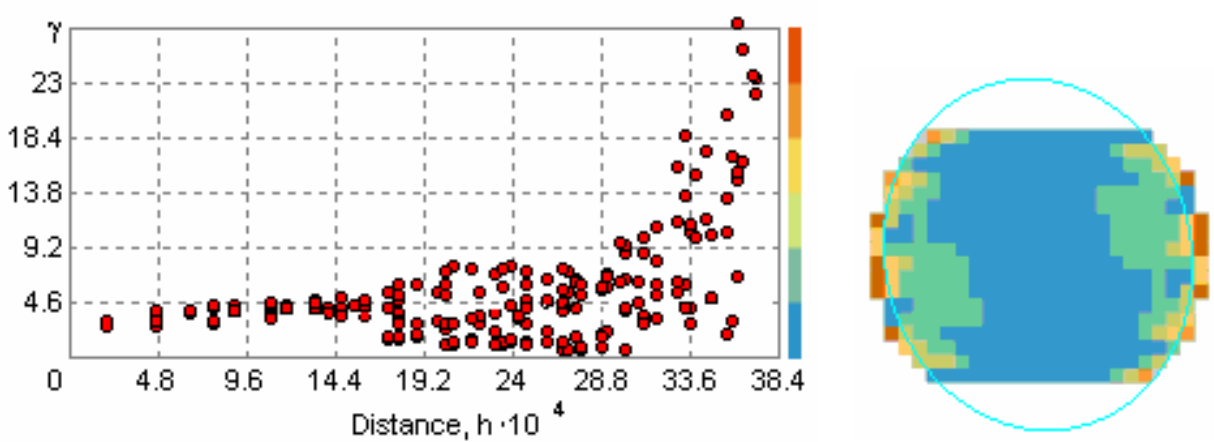

(b)
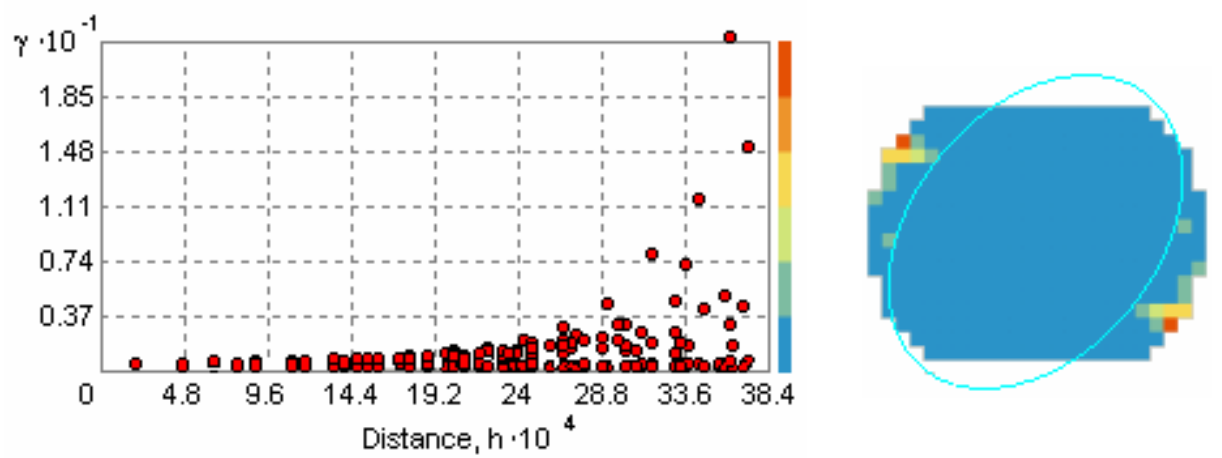

(c)
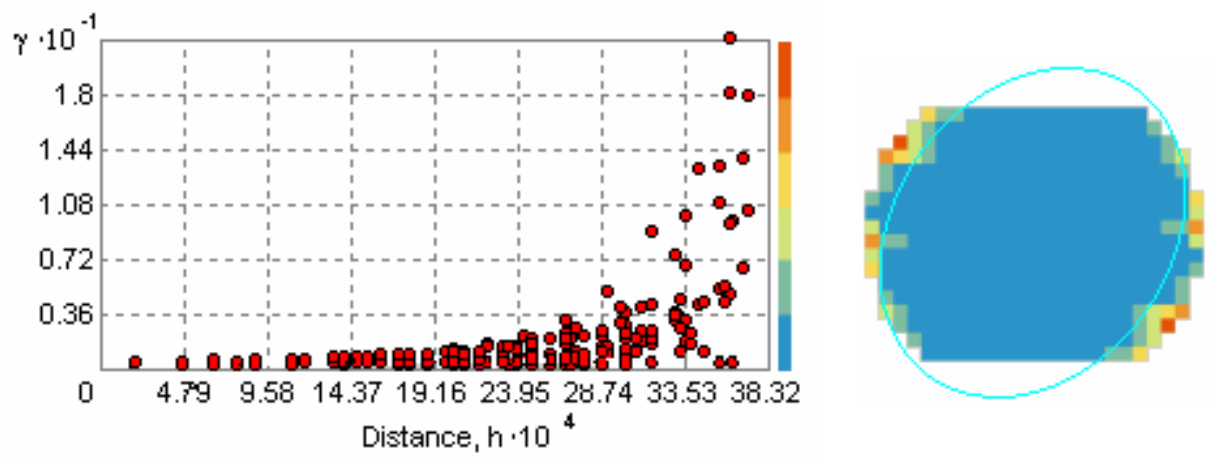

(d)

Figure 3. Semi- and surface variograms for the study area:

(a) February 2003, (b) May 2003, (c) July 2003 and (d) September 2003

\section{REFERENCES}

Burrough P.A. (1996), Principles of Geographical Information Systems for Land Resources Assessment, Clarendon Press, Oxford. 
Campbell J., Antoine D., Armstrong R., Arrigo K., Balch W., Barber R., Behrenfeld M., Bidigare R., Bishop J., Carr M.-E., Esaias W., Falkowski P., Hoepffner N., Iverson R., Kiefer D., Lohrenz S., Marra J., Morel A., Ryan J., Vedernikov V., Waters K., Yentsch C. and Yoder J. (2002), Comparison of algorithms for estimating ocean primary production from surface chlorophyll, temperature, and irradiance, Global Biogeochem. Cycles, 16(3), 1035.

Christaki U., Van Wambeke F. and Dolan,J.R. (1999), Nanoflagellates (mixotrophs, heterotrophs, and autotrophs) in the oligotrophic eastern Mediterranean: standing stocks, bacterivory and relationships with bacterial production, Mar. Ecol. Prog. Ser., 181, 297- 307.

D'Ortenzio F., Marullo F., Ragni M., Ribera d'Alcala M. and Santoleri R. (2002), Validation of empirical SeaWiFS algorithms for chlorophyll-a retrieval in the Mediterranean Sea. A case study for oligotrophic seas, Remote Sensing of Environment, 82, 79-94.

European Environment Agency (1998), Aquatic eutrophication in England and Wales: A proposed management strategy, European Environment Agency, Copenhagen, Denmark.

Fisher W.S., Malone T.C. and Giattina J.D. (2003), A pilot project to detect and forecast harmful algal blooms in the northern Gulf of Mexico, Environmental Monitoring and Assessment, 81, 373- 381.

Garcia C.A.E., Garcia V.M.T and McClain C.R. (2005), Evaluation of SeaWiFS chlorophyll algorithms in the Southwestern Atlantic and Southern Oceans, Remote Sensing of Environment, 95, 125-137.

Goovaerts P. (1997), Geostatistics for Natural Resources Evaluation, Oxford University Press, Oxford.

Gregg W.W. and Casey N.W. (2004), Global and regional evaluation of the SeaWiFS chlorophyll data set, Remote Sensing of Environment, 93, 463-479.

Herzfeld U.C. and Zahner O. (2001), A connectionist-geostatistical approach to automated image classification, applied to the analysis of crevasse patterns in surging ice, Computers \& Geosciences, 27, 499-512.

Iglesias-Rodriguez M.D., Brown C.W., Doney S.C., Kleypas J., Kolber D., Kolber Z., Hayes P.K. and Falkowski P.G. (2002), Representing key phytoplankton functional groups in ocean carbon cycle models: Coccolithophorids, Global Biogeochem. Cycles, 16(4), 1100.

Ignatiades L., Psarra S., Zervakis V., Pagou K., Souvermezogloy E., Assimakopoulou G. and Gotsis-Skretas O. (2002), Phytoplankton size-based dynamics in the Aegean Sea (Eastern Mediterranean), Journal of Marine Systems, 36, 11-28.

Kamykowski D., Zentara S.J., Morrison J.M. and Switzer A.C. (2002), Dynamic global patterns of nitrate, phosphate, silicate, and iron availability and phytoplankton community composition from remote sensing data, Global Biogeochem. Cycles, 16(4), 1077.

Karydis M. and Tsirtsis G. (1996), Ecological indices: a biometric approach for assessing eutrophication levels in the marine environment, The Science of the Total Environment, 186, 209-219.

Karydis M., Tsirtsis G. and Kitsiou D. (1995), Quantitative methodology for the estimation of coastal waters quality: the case of eutrophicated systems, Proceedings of the Conference of the Technical Chamber of Greece entitled: "Tourism and Environment in Insular Areas", Iraklion, Crete, pp. 130-143.

Kitsiou D. and Karydis M. (2000), Categorical mapping of marine eutrophication based on ecological indices, The Science of the Total Environment, 255, 113-127.

Kitsiou D., Tsirtsis G. and Karydis M. (2001), Developing and optimal sampling design: A case study in a Coastal Marine Ecosystem, Environmental Monitoring and Assessment, 71, 112.

Krasakopoulou E., Zervakis V., Souvermezoglou E. and Georgopoulos D. (2002), North-eastern Aegean sea: an effort to estimate steady-state N \& P budgets during September 1998, Mediterranean Marine Science, 3(1), 43-54.

Kucuksezgin F., Balci A., Kontas A. and Altay O. (1995), Distribution of nutrients and chlorophylla in the Aegean Sea, Oceanol. Acta, 18, 343- 352.

Lykousis V., Chronis G., Tselepides A., Price N.B., Theocharis A., Siokou-Frangou I., Van Wambeke F., Danovaro R., Stavrakakis S., Duineveld G., Georgopoulos D., Ignatiades L., Souvermezoglou A. and Voutsinou-Taliadouri F. (2002), Major outputs of the recent 
multidisciplinary biogeochemical researches undertaken in the Aegean Sea, Journal of Marine Systems, 33-34, 313-334.

Maritorena S. and Siegel D.A. (2005), Consistent merging of satellite ocean color data sets using a bio-optical model, Remote Sensing of Environment, 94, 429-440.

McClain C.R., Esaias W.E., Barnes W., Guenther B., Endres D., Hooker S.B., Mitchell B.G. and Barnes R. (1992), SeaWiFS Technical Report Series, Volume 3, SeaWiFS Calibration and Validation Plan, NASA Technical Memorandum 104566.

McClain C.R., Feldman G.C. and Hooker S.B. (2004), An overview of the SeaWiFS project and strategies for producing a climate research quality global ocean bio-optical time series, Deep Sea Res. II, 51, 5-42.

Moore J.K., Doney S.C., Kleypas J.A., Glover D.M. and Fung I.Y. (2002), An intermediate complexity marine ecosystem model for the global domain, Deep-Sea Research Part 2, Topical Studies in Oceanography, 49, 403- 462.

Oliver M.A. and Webster R. (1990), Kriging: A method of interpolation information systems, Inter. J. Geograph. Inform. Syst., 4(3), 313-332.

Pannatier Y. (1996), Statistics and Computing: Variowin, Software for Spatial Data Analysis in 2D, Springer-Verlag New York, Inc.

Poulos S.E., Drakopoulos P.G. and Colllins M.B. (1997), Seasonal variability in sea surface oceanographic conditions in the Aegean Sea (Eastern Mediterranean): an overview, Journal of Marine Systems, 13, 225-244.

Rodhe W. (1969), Crystallization of eutrophication concepts in Northern Europe; in Eutrophication: Causes, Consequences and Corrective, Nat. Acad. Sci./Nat. Res. Council, Publ. 1700, 50-64.

Siokou-Frangou I., Bianchi M., Christaki U., Christou E.D., Giannakourou A., Gotsis O., Ignatiades L., Pagou K., Pitta P., Psarra S., Souvermezoglou E., Van Wambeke F. and Zervakis V. (2002), Carbon flow in the planktonic food web along a gradient of oligotrophy in the Aegean Sea (Mediterranean Sea), Journal of Marine Systems, 33-34, 335-353.

Spokas K. Graff C., Morcet M. and Aran C. (2003), Implications of the spatial variability of landfill emission rates on geospatial analyses, Waste Management, 23(7), 599-607.

Stumpf R.P. (2001), Applications of satellite ocean color sensors for monitoring and predicting harmful algal blooms, Human and Ecological Risk Assessment, 7(5), 1363-U15.

Vidal Vázquez E., Vivas Miranda J.G. and Paz González A. (2005), Characterizing anisotropy and heterogeneity of soil surface microtopography using fractal models, Ecological Modelling, 182, 337-353.

Vollenweider R.A. (1992), Coastal marine eutrophication: principles and control. In: Marine coastal eutrophication. London, Vollenweider R.A., Marchetti R., Viviani R. (eds)., Elsevier, 1-20.

Washington H.G. (1984), Diversity, biotic and similarity indices: a review with special relevance to aquatic ecosystems, Water Resources, 18(6), 653-694.

Young K., Morse G.K., Scrimshaw M.D., Kinniburgh J.H., Macleod C.L., Lester J.N. (1999), The relation between phosphorus and eutrophication in the Thames catchment, U.K., The Science of the Total Environment, 228(2-3), 157-183.

Zervakis V. and Georgopoulos D. (2002), Hydrology and circulation in the North Aegean (eastern Mediterranean) throughout 1997 and 1998, Mediterranean Marine Science, 3(1), 5-19. 